nuestras excelencias sin necesidad de hipérbole y sin posibilidad de mentirijilla.

El Instituto del Cinema Educacional podrá hacer en nuestro favor lo que no ha realizado institución europea alguna, en el sentido de excitar a las empresas a la divulgación gráfica de nuestro continente; en el de articular los trabajos ya logrados y darles unidad, y en el de purificar, con el solo incremento del cine geográfico e histórico de índole documental, la plaga del cine imbécil o perverso que anega nuestros mercados. No necesitará para lo último combatir a ninguna empresa explícitamente; bastará con que informe a los pueblos de América respecto del material disponible de películas con asunto nuestro, con panorama, costumbres e historia nuestras. Los pueblosibero-americanos harán la selección por sí mismos.

Queda para un segundo artículo el examinar el cine documental aplicado a la divulgación de las antiguas civilizaciones de América, tan desdeñadas, tan estudiadas a medias y tan apresuradamente avizoradas por el europeo.G A B R I E L A M I S T R L.

Exclusivo para Atenea en Chile.

\title{
La manía de imitar
}

TRENTE a los problemas que se plantearon desde los orígenes de su vida libre, la América Latina atendió más a menudo a buscar ejemplos que soluciones propias.

Nunca se preguntó:

- ¿Qué es necesario hacer?

Fruto de una tradición dogmática, su actividad resultó ante todo memorista, y la interrogación se concretó, más bien, en estas palabras:

- ¿Qué es lo que hicieron otros?

El sistema - absolutamente contrario al que dió nacimiento en el norte anglo sajón a una actividad poderosa y original-adormeció a los pueblos del sur en una atmósfera sobrecargada de imitaciones. En el orden político, sociológico, artístico, municipal, el ideal supremo fué trasplantar lo que existía en las naciones, en las ciudades o en las almas que admirábamos desde lejos. 
Así surgió una civiilzación, fastuosa a veces y sorprendente por su vigor, pero desprovista de personalidad. Los conocimientos no fueron transmutados, no se les dió forma autónoma. El progreso cuajó en los moldes del convencionalismo. Se adoptó lo bueno y lo malo, sin discernir. $\mathrm{Y}$ el adelanto residió más en las exterioridades que en los resortes interiores. No podía ser de otro modo, puesto que ese progreso no nacía del medio, ni estaba estrechamente ligado con él.

Desde las Constituciones y las formas políticas, hasta el uniforme de los soldados, pasando por la edificación, las modas y la ideología, cada paso marcó un trasunto fiel de lo que se había visto o leído, posponiendo casi siempre la concordancia y la necesidad de adquirir fisonomía, sacrificando en todo momento las impulsiones del propio ser en aras de 10 artificioso y de lo ajeno. Las naciones nacientes se calificaron a sí mismas de nuevas Grecias o nuevas Prusias, las ciudades en embrión aspiraron a ser la "Atenas" o el "París" de América, los intelectuales el "Musset», el "Zola» o el "Castelar» de tal o cual república. En vez de crear con el esfuerzo diario valores nuevos y una civilización diferenciada, ensayamos vivir del reflejo y de las rentas de otras civilizaciones. En vez de tener caballo propio, montamos a la grupa de los demás.

Una pereza engreída, o resignada, se comunicó así a los más diversos órdenes, cono si no fuera ya posible inventar o renovar, como si todo debiera ser transplantado del escenario grande al chico, como si la única aspiración fincase en multiplicar doublures de lo que nació de otras evoluciones sociales, bajo otros climas, con otros componentes, en otros siglos.

Esta manía de imitar ha sido el origen de la situación disminuida en que se hallan nuestras repúblicas, de las dificultades por que hemos tenido que atravesar después de la guerra y de las graves amenazas que se ciernen sobre nosotros.

Si subrayamos la saturación de inspiraciones extranjeras es, sobre todo, porque en la órbita del Gobierno ella impidió toda concepción o doctrina propia, no sólo en lo que se refiere a los asuntos interiores, sino también, y sobre todo, en lo que atañe a la acción internacional.

Ni se sospechó siquiera que pudieran existir entre nosotros conflictos diferentes de los que veíamos en los pueblos cuya vida imitábamos. Así se desarrollaron las colectividades sin afrontar el primordial problema étnico, que imponía el estudio de la convivencia con el aborigen, o, según las zonas, la dosificación de las inmigraciones. Así continuamos en el orden comercial el monótono juego de exportar materias primas e 
importar productos manufacturados, sancionando el colonialismo virtual, aceptando la etapa ganadera y agrícola como estado definitivo. Así crecimos confiadamente sin averiguar lo que representaba la influencia anglo sajona; influencia de la cual sólo llegaron a tener noticia nuestros dirigentes después de la guerra, cuando se hizo patente en Europa y cuando de los mismos Estados Unidos nos llegaron las voces que señalaban la sujeción.

Todo ello se complicó con un envanecimiento prematuro que interpretó toda reserva como síntoma antipatriótico. Examinar las cuestiones, investigar el porvenir, equivalió a poner en duda la predestinación de nuestras repúblicas y la supersabiduría de los augures que guiaban sus pasos. ¿Cómo admitir que alguien pudiera saber más que nuestros «hombres de gobierno", que habían adquirido su ciencia en el comité, combinando elecciones, o en la montonera, organizando guerrillas? ¿Cómo podían dejarnos subir a nosotros, los ilusos, aỉ pontón anclado en el pasado sobre el cual ellos tenían la ilusión de navegar?

La evolución que se anuncia en toda la América Latina viene a redimirnos de estos errores. Hombres nuevos con ideas nuevas han de resolver los problemas propios basándose en sistemas adecuados a las necesidades y a la situación de cada zona. Al margen de los empirismos y de las jactancias, habrá que encararse al fin con la obra y decir: vamos a hacer una. Patria.-M A N UE L U G A R T E.

Exclusivo para Atenea en Chile.

\section{Pentágono alrededor de «EI Roto»}

\section{A: LA DIATRIBA}

- $L$ LENTOR don Joaquín Edwards Bello presenta como "definitiva» la última edición de El Roto, publicada en 1929. Tal advertencia permite entrar en tranquila posesión de los valores de esta novela costumbrista, cuyo debut ocurrió hace más de dos lustros. En realidad, las modificaciones introducidas no son esenciales. Por eso El Roto conserva su primigenio interés. El señor Edwards Bello ha tenido la prudencia de efectuar leves retoques, meros adornos que no alteran el contenido vital de su obra. $\mathrm{Y}$ es que en 